\title{
SEASONAL CHANGES IN THE ABUNDANCE AND BIOMASS OF ZOOPLANKTON FROM SHALLOW MUDFLAT RIVER-ESTUARINE SYSTEM IN PERSIAN GULF
}

\author{
FARHADIAN, O.* \& POULADI, M. \\ Department of Natural Resources, Isfahan University of Technology, Isfahan 84156-83111, Iran. \\ ${ }^{*}$ Corresponding author: farhadyo@yahoo.com, omfarhad@cc.iut.ac.ir
}

\begin{abstract}
Farhadian, O. \& Pouladi, M. (2014) Seasonal Changes in the abundance and biomass of zooplankton from shallow mudflat river-estuarine system in Persian Gulf . Braz. J. Aquat. Sci. Technol. 18(2):19-29. elSSN 1983-9057. DOI: 10.14210/bjast.v18n2.p19-29 The present study was designed to investigate the seasonal changes in the abundance and biomass of zooplankton and their relationships with water quality parameters in mudflat shallow estuary, Helleh River (HR), Persian Gulf (Iran). The zooplankton consisted of Acartia, Euterpina, Oithona, Oncaea, Paracalanus, Corycaeus, Labidocera, Macrosetella, Microsetella, Temora, copepod copepodid, copepod nauplii, Barnacle, Polychaeta, Conchoecia (Ostracoda), Hyperid, Decapoda (zoea and megalopa), Actinula, Echinopluteus, Mollusca, Tintinnopsis, Boliopsis, Discorbis, Diastylis, Siphonophora and Phialidium, Pratylenchus, Oikopleura, fish eggs and fish larvae. The maximum biomass was estimated at estuary mouth in all seasons, the highest values in autumn $\left(97.8-255.6 \mathrm{mg} / \mathrm{m}^{3}\right)$ and the lowest in winter $\left(5.5-68.2 \mathrm{mg} / \mathrm{m}^{3}\right)$. The seasonal abundance (density) of zooplankton was $21,237 \pm 2,419,45,739 \pm 6,053,5,242 \pm 648$, and $12,905 \pm 1,867$ ind. $/ \mathrm{m}^{3}$ in summer, autumn, winter and spring, respectively. There was a significant correlation $(P<0.01)$ between zooplankton abundance as well as biomass with salinity, dissolved oxygen and chlorophyll $a$. Based on PCA (Principal Component Analysis), the most important factors in mudflat shallow river-estuarine system that could describe most changes of biomass and abundance of zooplankton were salinity, chlorophyll a, temperature and $\mathrm{pH}$, respectively.
\end{abstract}

Keywords: Plankton; Estuary; Distribution; Temporal varation; Coastal waters.

\section{INTRODUCTION}

Estuaries are one of the high productive ecosystems (Mann, 2000; Miller Jr. \& Spoolman, 2012) that are important both ecologically and economically. They are the appropriate places for spawning, and feeding of many aquatic larvae, including fish and shrimp (Ross \& Epperly, 1985; Deegan \& Day, 1985); they are also the protected area for wildlife such as migratory birds (Miller Jr \& Spoolman, 2012). Estuaries are places for human activities such as navigation, shipping, urban, industrial wastes (Carlberg, 1980; Chau, 1999; Kress et al., 2002), and human settlements around them (ChiFang et al., 2004), fishing, aquaculture (Jennerjahn et al., 2004) and the resorts activities (Baird et al., 1986; Costanza et al., 1989). Furthermore, other activities such as deforestation, intensive farming, raising livestock, sand mining, river diversion, and conversion of mangrove forests into shrimp/fish ponds may change estuaries and the marine environments (Morton \& Blackmore, 2001; Jennerjahan et al., 2004).

Estuaries are extremely variable in their physical (e.g. salinity, light, temperature and tide), chemical (e.g. $\mathrm{NO}_{3}, \mathrm{PO}_{4}$, dissolved oxygen and silicon) and biological parameters (Suthers \& Rissik, 2009). These physicochemical characteristics are the important factors that affect abundance, biomass, and population growth of zooplankton in estuaries (Joseph \& Yamakanamardi, 2011). Zooplankton populations are highly sensitive to environmental variation. Therefore, changes in their abundance, biomass and diversity can clearly show that they are ecologically important (Jayansinghe, 2004; Suthers \& Rissik, 2009). Their reproductive cycles, growth, reproduction and survival rates are all important factors that affect fish resources (Harris et al., 2000). On the other hand, zooplankton assemblages were used to monitor certain aspects of the environment including hydrographic events, eutrophication, pollution, global warming and environmental problems in terms of long-term changes (Omori \& Ikeda, 1984). Since the composition and abundance of zooplankton are different at various aquatic environments, their biomass is ecologically very important.

The zooplankton density and biomass vary in different regions of the world. For instance, the zooplankton density ranged $15,000-255,000 \mathrm{ind} . / \mathrm{m}^{3}$ in Cuba Bay (Zaballa \& Gaudy, 1996), 45,261ind./ $\mathrm{m}^{3}$ in Bahuda estuary (Mishra \& Panigrahy, 1999), 12, 918 ind. $/ \mathrm{m}^{3}$ (adult copepod density of 2,927ind. $/ \mathrm{m}^{3}$ ) from Straits of Malacca, Malaysia (Rezaei-Marnani, 2002), and 16,040 to 119,810 ind. $/ \mathrm{m}^{3}$ in Langat river estuary, Malaysia (Jayasinghe, 2004). Similarly, zooplankton biomass can greatly vary among estuaries, from time to time and place to place within an estuary (Knox, 1986). Srinivasan \& Santhanam (1991) recorded a dry biomass of $738 \mathrm{mg} / \mathrm{m}^{3}$ for zooplankton of Pullavazhi, southeast coast of India. Jayasinghe (2004) stated dry biomass from 10.7 to $950.8 \mathrm{mg} / \mathrm{m}^{3}$ in the Langat river estuary, Malaysia. Rezaei-Marnani (2002) reported 
zooplankton biomass of 48.5 to $122.6 \mathrm{mg}$ dry weight $/ \mathrm{m}^{3}$ during different cruises in Straits of Malacca, Malaysia. Zooplankton studies have been carried out in different parts of Persian Gulf (Grice \& Gibson, 1978; Savari, 1982; Michel \& Herring, 1984; Khodaddi, 1990; ROPME, 2003; Rabbanih et al., 2011). Michel \& Herring (1984) estimated density of 45,000 ind. $/ \mathrm{m}^{3}$ for total zooplankton and $27,779 \mathrm{ind} . / \mathrm{m}^{3}$ for copepods from northern parts of Persian Gulf. Rabbanih et al. (2010) reported density of $1,470.5 \mathrm{ind} . / \mathrm{m}^{3}$ at warm seasons (spring and summer) and $611.1 \mathrm{ind} . / \mathrm{m}^{3}$ at cold seasons (autumn and winter) by using a $100 \mu \mathrm{m}$ plankton net from different stations of the northern part of Persian Gulf, Busheher waters. ROPME (2003) reported that the highest concentration of nutrients $\left(\mathrm{NO}_{3}, \mathrm{PO}_{4}\right.$ and $\mathrm{SiO}_{4}$ ) came to Persian Gulf from Iranian coastal waters. Therefore, proper management of nutrients loaded from rivers to Persian Gulf, and determination of the biomass and composition of planktonic assemblages at different parts of estuarine rivers, especially at estuarine waters, are essential to assess environmental conditions.

Helleh River (HR) is a permanent river with 170 $\mathrm{km}$ length that is discharged to the Persian Gulf at 54 $\mathrm{km}$ far from Busheher. The HR originates from southern part of Zagros Mountains, Iran. This river receives the Dalaki and Shapur rivers at the west of Shiraz, Fars province. The HR basin has an ecological importance for migratory birds, wildlife and aquatic organisms, especially fish. The ichthyofauna of HR basin was studied by Teimori et al. (2010). The HR estuary consists of brackish and freshwater lagoons with different depths (Table 1) throughout the year. Therefore, research on abundance, biomass, and composition of zooplankton is important for fishery management at HR estuary.

The main objective of this study was to determine zooplankton abundance, biomass and their possible ecological relationships with water quality parameters in HR estuary, Boushehr, the northern part of Persian Gulf, Iran.

\section{MATERIALS AND METHODS}

\section{Study area and sampling}

The study area was located in the HR estuary $\left(28^{\circ} 20^{\prime} \mathrm{N} 51^{\circ} 30^{\prime} \mathrm{E}\right)$, in the southwestern part of Busheher province, north of Persian Gulf, Iran (Fig. 1). Along HR estuary, five sampling stations (Figure 1, Table 1) were determined based on environmental gradients of flow dynamics and mixing of fresh and costal water, depth, tides, river flow and geomorphological features.

Seasonal samplings were carried out in the middle of each season for a one-year period from August 2011 to April 2012. Measurements were made of water temperature, Secchi depth, dissolved oxygen (YSI 51 Oxygenmeter, OH, USA), pH (WTW 330 pHmeter, Weilheium, Germany) and salinity in situ. For measur-

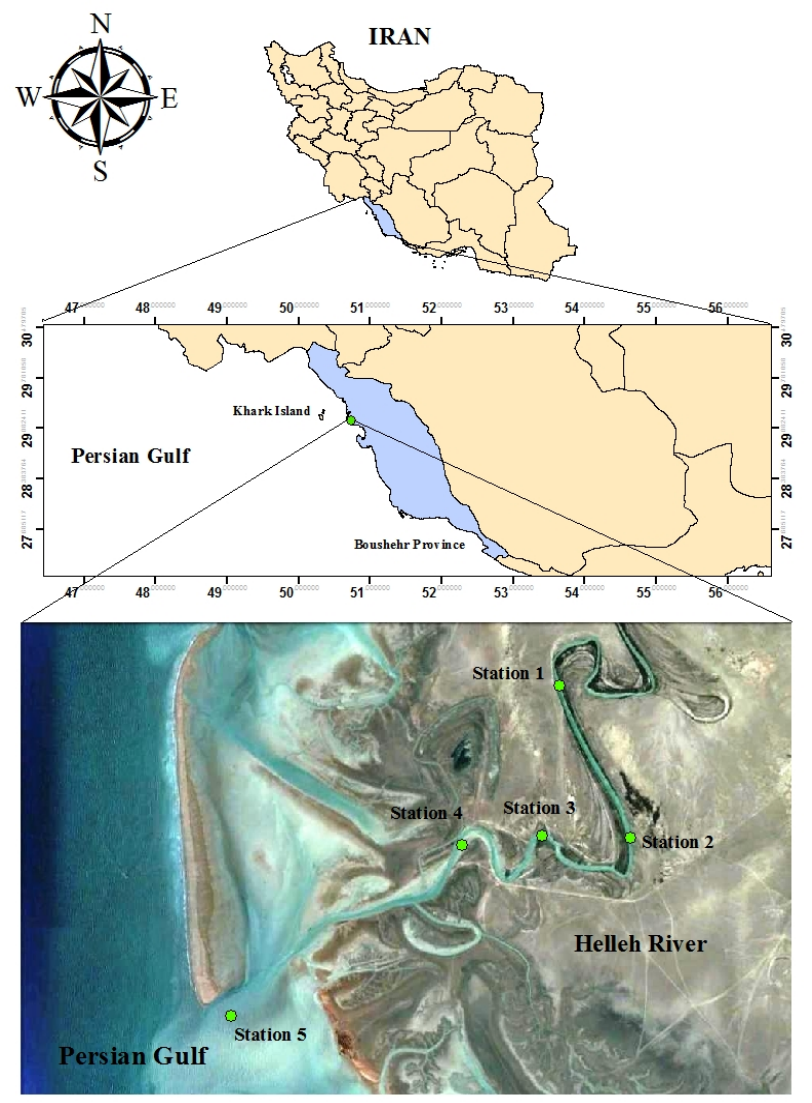

Figure 1. Stations and geographic locations in Helleh River estuary, Persian Gulf, Iran.

Table 1 - Sampling stations and their depth $(m)$ in each season at Helleh River estuary, Persian Gulf, Iran.

\begin{tabular}{|c|c|c|c|c|c|c|c|}
\hline \multirow[b]{2}{*}{ Stations } & \multirow{2}{*}{\multicolumn{2}{|c|}{ Lat. N }} & \multirow[b]{2}{*}{ Long. E } & \multicolumn{4}{|c|}{ Depth (m) } \\
\hline & & & & Summer 2011 & Autumn 2011 & $\begin{array}{c}\text { Winter } \\
2012 \\
\end{array}$ & $\begin{array}{c}\text { Spring } \\
2012 \\
\end{array}$ \\
\hline 1 & $29^{\circ}$ & $10^{\prime} 21.9 "$ & $50^{\circ} 40^{\prime} 38.5^{\prime \prime}$ & 0.73 & 0.88 & 0.96 & 0.90 \\
\hline 2 & $29^{\circ}$ & 09' 37.1" & $50^{\circ} 41^{\prime} 03.2^{\prime \prime}$ & 2.14 & 2.30 & 2.38 & 2.24 \\
\hline 3 & $29^{\circ}$ & $09^{\prime} 36.8 "$ & $50^{\circ} 40^{\prime} 32.9^{\prime \prime}$ & 2.21 & 2.45 & 2.37 & 2.32 \\
\hline 4 & $29^{\circ}$ & $09^{\prime} 35.3^{\prime \prime}$ & $50^{\circ} 40^{\prime} 04.9^{\prime \prime}$ & 1.62 & 1.80 & 2.02 & 1.96 \\
\hline 5 & $29^{\circ}$ & $08^{\prime} 39.3^{\prime \prime}$ & $50^{\circ} 38^{\prime} 54.1^{\prime \prime}$ & 2.35 & 2.56 & 2.78 & 2.50 \\
\hline
\end{tabular}


ing chlorophyll a, $\mathrm{NO}_{3}$ and $\mathrm{PO}_{4}$, three water samples of 3-L were collected from the water column at the sampling sites by a Van Dorn water sampler. The amounts of chlorophyll a, $\mathrm{NO}_{3}$ and $\mathrm{PO}_{4}$ were determined according to Parsons et al. (1984) in the laboratory. For phytoplankton studies, the water samples were collected from surface layer. The Lugol's iodine solution $(10 \mathrm{~mL}$ for $200 \mathrm{~mL}$ sample) was used as the fixative of phytoplankton samples. The zooplankton samples were collected from middle of each season between 0800 and $1200 \mathrm{~h}$ by vertical haul using zooplankton net (bolting silk, $140 \mu \mathrm{m}$ mesh size, and diameter of $25 \mathrm{~cm}$ ) from the sampling sites with three sub-samples in the high tide of water. Zooplankton was immediately fixed in 5\% formalin for the identification and quantitative estimation of relative density (abundance) of each zooplankton category.

\section{Zooplankton}

Zooplankton samples were initially put in their major taxonomic groups and enumeration was determined by using stereo microscopes (Olympus SZ6045, Japan) with the magnification of 6 . Since the majority of the present study was comprised of copepods, the adult individuals were separated from the sub-samples and preserved in small glass bottles using $70 \%$ ethyl alcohol for species identification using zooplankton keys (Monchenko, 1974; Grindley, 1981; Maguire et al., 1985; Nishida, 1985, 1985; Todd \& Laverack, 1991; Chihara \& Murano, 1997). For the estimation of zooplankton density, each sample was kept in the measuring cylinder and adjusted to a known volume by adding distilled water, and then transferred to a wide mouth $250 \mathrm{~mL}$ glass beaker. Next, a magnetic stirrer was set on the lowest speed for gently mixing of zooplankton sample and a sub-sample was taken using a Stemple pipette while it was mixed. The sub-samples were transferred to a zooplankton counting chamber (Bogorov's chamber) and zooplankton was counted under a dissecting microscope (Omori \& Ikeda, 1984). The density of zooplankton was estimated according to formula of $D=\left(N / V_{1}\right) \times\left(V_{2} \times F\right) / N$, where $D=$ zooplankton density, $\mathrm{N}=$ sub-sample individuals, $\mathrm{V}_{1}=$ sub-sample volume, $\mathrm{V}_{2}=$ volume of original sample, $\mathrm{V}=$ water filtered volume by plankton net, and $\mathrm{F}=$ net filtration efficiency $(90 \%)$. Zooplankton dry biomass was calculated by Postel et al (2000) method through filtration and oven dried at $60^{\circ} \mathrm{C}$ for 24 hours.

\section{Statistical Analysis}

One-way ANOVA was performed to test significant seasonal differences in zooplankton density and water quality parameters. Data were presented as means \pm standard error of means. Differences in means were compared by Duncan's Multiple Range Test. All percentage data were Arcsine-square root transformed and then tested for normal distribution and homogeneity of variance before performing ANOVA (Zar, 1984). All statistical analysis was carried out using SPSS, version 11.5. Pearson correlation was calculated for the abundance, biomass and water parameters.

\section{RESULTS}

\section{Water quality}

Seasonal average of temperature and dissolved oxygen and chlorophyll a were $32.4^{\circ} \mathrm{C}, 6.8 \mathrm{mg} / \mathrm{L}$ and $110 \mu \mathrm{g} / \mathrm{L}$ in summer; $19.2^{\circ} \mathrm{C}, 7.1 \mathrm{mg} / \mathrm{L}$ and $380 \mu \mathrm{g} / \mathrm{L}$ in autumn; $13.6^{\circ} \mathrm{C}, 11.3 \mathrm{mg} / \mathrm{L}$ and $50 \mu \mathrm{g} / \mathrm{L}$ in winter; $23^{\circ} \mathrm{C}, 8.4 \mathrm{mg} / \mathrm{L}$ and $240 \mu \mathrm{g} / \mathrm{L}$ in spring, respectively. Seasonal average of Secchi depth, salinity and $\mathrm{pH}$ were $44.4 \mathrm{~cm}, 39.6 \mathrm{ppt}$ and 8.1 in summer; $48 \mathrm{~cm}$, $37.6 p p t$ and 8.1 in autumn; $50 \mathrm{~cm}, 17.2 \mathrm{ppt}$ and 8.1 in winter; $45.2 \mathrm{~cm}, 27.8 \mathrm{ppt}$ and 8.2 in spring, respectively (Table 2). Seasonal average of $\mathrm{PO}_{4}$ and $\mathrm{NO}_{3}$ were 200 and $30 \mu \mathrm{g} / \mathrm{L}$ in summer; 190 and $27 \mu \mathrm{g} / \mathrm{L}$ in autumn; 120 and $23 \mu \mathrm{g} / \mathrm{L}$ in winter; and 190 and $29 \mu \mathrm{g} / \mathrm{L}$ in spring, respectively.

\section{Zooplankton}

The zooplankton consisted of Acartia sp., Euterpina sp., Oithona spp., Oncaea sp., Paracalanus sp., Corycaeus sp., Labidocera sp., Macrosetella sp., Microsetella sp., Temora sp., copepod copepodid, copepod nauplii, Barnacle larvae, Polychaeta larvae, Conchoecia sp., Hyperid larvae, Decapoda larvae (zoea and megalopa), Actinula larvae, Echinopluteus larvae, Mollusca larvae, Tintinnopsis sp., Ctenophora larvae (Boliopsis sp.), Protozoa (Discorbis sp.), cumacea (Diastylis sp.), Cnidaria larvae (Siphonophora and Phialidium), Nematoda larvae (Pratylenchus spp.), Urocordata (Oikopleura spp.), fish eggs and fish larvae (Tables 3-6). Among identified zooplanktons, Acartia sp. and copepod nauplius had highest density, respectively.

The seasonal abundance (density) of zooplankton was $21,237 \pm 2,419,45,739 \pm 6,053,5,242 \pm 648$, and $12,905 \pm 1,867 \mathrm{ind} . / \mathrm{m}^{3}$ in summer, autumn, winter and spring, respectively. The highest amount of zooplankton density was recorded at station 5 (estuary mouth) throughout the year (Tables 3-6). Dry biomass of zooplankton at HR estuary is presented in Tables 5-8. Amounts of dry biomass at stations of 1, 2, 3, 4, and 5 were $59.9,69.8,47.9,86.8$ and $99.4 \mathrm{mg} / \mathrm{m}^{3}$ in summer; $97.9,146.5,184.4,140.7$ and $255.6 \mathrm{mg} / \mathrm{m}^{3}$ in autumn; $11,11.6,8.3,5.5$ and $68.2 \mathrm{mg} / \mathrm{m}^{3}$ in winter; and $27.4,28.5,43.6,47.6$ and $102.5 \mathrm{mg} / \mathrm{m}^{3}$ in spring, 
Table 2 - Average of water quality parameters in different seasons at Helleh River (HR) estuary.

\begin{tabular}{lcccc}
\hline \hline \multicolumn{1}{c}{ Parameter } & Summer 2011 & Autumn 2011 & Winter 2012 & Spring 2012 \\
\hline Temperature $\left({ }^{\circ} \mathrm{C}\right)$ & $32.4 \pm 1.1^{\mathrm{d}}$ & $19.2 \pm 0.1^{\mathrm{b}}$ & $13.6 \pm 0.2^{\mathrm{a}}$ & $23 \pm 0.5^{\mathrm{c}}$ \\
Salinity $(\mathrm{ppt})$ & $39.6 \pm 1.2^{\mathrm{b}}$ & $37.6 \pm 1.9^{\mathrm{b}}$ & $17.2 \pm 6.3^{\mathrm{a}}$ & $27.8 \pm 6.4^{\mathrm{ab}}$ \\
$\mathrm{DO}(\mathrm{mg} / \mathrm{L})$ & $6.8 \pm 0.1^{\mathrm{a}}$ & $7.1 \pm 0.1^{\mathrm{a}}$ & $11.3 \pm 0.3^{\mathrm{c}}$ & $8.4 \pm 0.1^{\mathrm{b}}$ \\
$\mathrm{pH}$ & $8.1 \pm 0.01^{\mathrm{a}}$ & $8.1 \pm 0.03^{\mathrm{ab}}$ & $8.1 \pm 0.01^{\mathrm{a}}$ & $8.2 \pm 0.02^{\mathrm{b}}$ \\
Secchi depth $(\mathrm{cm})$ & $44.4 \pm 0.7^{\mathrm{a}}$ & $48 \pm 0.7^{\mathrm{a}}$ & $50 \pm 1.6^{\mathrm{a}}$ & $45.2 \pm 1.8^{\mathrm{a}}$ \\
$\mathrm{Chlo} . \mathrm{a}(\mu \mathrm{g} / \mathrm{L})$ & $110 \pm 20^{\mathrm{c}}$ & $380 \pm 50^{\mathrm{a}}$ & $50 \pm 10^{\mathrm{d}}$ & $240 \pm 10^{\mathrm{b}}$ \\
$\mathrm{PO}_{4}(\mu \mathrm{g} / \mathrm{L})$ & $200 \pm 50^{\mathrm{a}}$ & $190 \pm 30^{\mathrm{a}}$ & $120 \pm 30^{\mathrm{a}}$ & $190 \pm 30^{\mathrm{a}}$ \\
$\mathrm{NO}_{3}(\mu \mathrm{g} / \mathrm{L})$ & $30 \pm 7^{\mathrm{a}}$ & $27 \pm 3^{\mathrm{a}}$ & $23 \pm 4^{\mathrm{a}}$ & $29 \pm 2^{\mathrm{a}}$ \\
\hline \hline
\end{tabular}

*Means in the same row sharing a common superscript are not significantly different $(P>0.05)$.

Table 3 - Mean ( \pm SE) abundance and dry biomass of zooplankton at different stations of Helleh River estuary in summer.

\begin{tabular}{|c|c|c|c|c|c|c|}
\hline \multirow[t]{2}{*}{ Zooplankton } & & \multicolumn{5}{|c|}{ Stations } \\
\hline & & 1 & 2 & 3 & 4 & 5 \\
\hline \multirow[t]{3}{*}{ Polychaete } & Tomopteris & 0 & 0 & $333 \pm 49$ & $113 \pm 12$ & $226 \pm 24$ \\
\hline & Trochophore & 0 & $266 \pm 28$ & 0 & 0 & $340 \pm 37$ \\
\hline & Veliger & $110 \pm 6$ & $340 \pm 42$ & 0 & 0 & $1246 \pm 137$ \\
\hline \multirow[t]{3}{*}{ Calanoidae } & Acartia sp. & $3000 \pm 176$ & $2493 \pm 311$ & $2889 \pm 430$ & $2833 \pm 311$ & $1473 \pm 162$ \\
\hline & Paracalanus sp. & $4444 \pm 261$ & $6006 \pm 749$ & $1110 \pm 165$ & $4873 \pm 536$ & $1813 \pm 199$ \\
\hline & Temora sp. & $333 \pm 19$ & $680 \pm 84$ & 0 & $1133 \pm 124$ & $906 \pm 99$ \\
\hline Cyclopoidae & Oithona spp. & $3777 \pm 222$ & $793 \pm 98$ & $1777 \pm 264$ & $113 \pm 12$ & $4306 \pm 474$ \\
\hline \multirow[t]{2}{*}{ Poecilostomatoida } & Oncaea sp. & 0 & $113 \pm 14$ & $444 \pm 66$ & $266 \pm 24$ & 0 \\
\hline & Corycaeus sp. & $4000 \pm 235$ & 0 & 0 & $3371 \pm 371$ & 0 \\
\hline \multirow[t]{2}{*}{ Harpacticoida } & Microsetella sp. & 0 & 0 & $444 \pm 66$ & $680 \pm 74$ & 0 \\
\hline & Macrosetella sp. & 0 & 0 & 0 & 0 & $680 \pm 74$ \\
\hline \multirow[t]{2}{*}{ Copepoda larvae } & Copepodid & $444 \pm 26$ & $4080 \pm 509$ & $3889 \pm 579$ & $4760 \pm 523$ & $3966 \pm 436$ \\
\hline & Copepoda nauplii & 0 & $2153 \pm 268$ & $3555 \pm 529$ & $3060 \pm 336$ & $9180 \pm 1010$ \\
\hline Ostracoda & Conchoecia spp. & 0 & $113 \pm 14$ & 0 & 0 & 0 \\
\hline \multirow[t]{2}{*}{ Decapoda (Hyoplax frater) } & Crab zoea & 0 & $113 \pm 14$ & 0 & 0 & 0 \\
\hline & Crab egg & 0 & $266 \pm 28$ & 0 & 0 & 0 \\
\hline Cirripedia & Barnacle Cyprid larvae & 0 & 0 & $222 \pm 33$ & 0 & $566 \pm 62$ \\
\hline Amphipoda & Hyperia & 0 & $906 \pm 113$ & $555 \pm 82$ & 0 & $1360 \pm 149$ \\
\hline \multirow[t]{2}{*}{ Urochordata } & Fish embryo & $222 \pm 131$ & 0 & 0 & 0 & 0 \\
\hline & Oikopleura sp. & 0 & $266 \pm 28$ & 0 & 0 & 0 \\
\hline Cnidaria & Actinula larva & 0 & $113 \pm 14$ & 0 & 0 & \\
\hline Echinodermata & Echinopluteus larvae & $110 \pm 16$ & $680 \pm 84$ & 0 & 0 & $113 \pm 12$ \\
\hline \multirow[t]{2}{*}{ Mollusca } & Cephalopoda larvae & 0 & $1020 \pm 127$ & $666 \pm 99$ & $793 \pm 87$ & 0 \\
\hline & Gasteropod larvae & $222 \pm 131$ & 0 & $222 \pm 33$ & $113 \pm 12$ & $906 \pm 99$ \\
\hline Protozoa & Globigerinid & $222 \pm 131$ & 0 & 0 & 0 & 0 \\
\hline \multicolumn{2}{|l|}{ Unidentified invertebrate eggs } & $333 \pm 19$ & $1360 \pm 169$ & $666 \pm 99$ & $453 \pm 49$ & $793 \pm 87$ \\
\hline \multicolumn{2}{|l|}{ Total abundance (ind. $/ \mathrm{m}^{3}$ ) } & $17217 \pm 1373$ & $21761 \pm 2694$ & $16772+2494$ & $22561 \pm 2471$ & $27874 \pm 3061$ \\
\hline \multicolumn{2}{|l|}{ Seasonal abundance (ind. $/ \mathrm{m}^{3}$ ) } & & & $21237 \pm 2419$ & & \\
\hline \multicolumn{2}{|l|}{ Dry biomass (mg/m3) } & 59.5 & 69.8 & 47.9 & 86.8 & 99.3 \\
\hline \multicolumn{2}{|c|}{ Seasonal mean dry biomass $(\mathrm{mg} / \mathrm{m} 3)$} & & & $72.7 \pm 10.3$ & & \\
\hline
\end{tabular}


Braz. J. Aquat. Sci. Technol., 2014, 18(2):19-29.

Table 4 - Mean $( \pm$ SE) abundance and dry biomass of zooplankton at different stations of Helleh River estuary in autumn.

\begin{tabular}{|c|c|c|c|c|c|c|}
\hline \multirow[t]{2}{*}{ Zooplankton } & & \multicolumn{5}{|c|}{ Stations } \\
\hline & & 1 & 2 & 3 & 4 & 5 \\
\hline Polychaete & $\begin{array}{l}\text { Tomopteris } \\
\text { Trochophore } \\
\text { Veliger }\end{array}$ & $\begin{array}{l}181 \pm 25 \\
181 \pm 25 \\
181 \pm 25\end{array}$ & $\begin{array}{c}0 \\
0 \\
362 \pm 55\end{array}$ & $\begin{array}{c}0 \\
370 \pm 47 \\
0\end{array}$ & $\begin{array}{c}0 \\
0 \\
384 \pm 39\end{array}$ & $\begin{array}{c}0 \\
726 \pm 101 \\
0\end{array}$ \\
\hline Calanoidae & $\begin{array}{l}\text { Acartia sp. } \\
\text { Paracalanus sp. } \\
\text { Labidocera sp. }\end{array}$ & $\begin{array}{c}4717 \pm 656 \\
0 \\
0\end{array}$ & $\begin{array}{c}3084 \pm 469 \\
181 \pm 27 \\
0\end{array}$ & $\begin{array}{c}1295 \pm 167 \\
0 \\
2777 \pm 360\end{array}$ & $\begin{array}{c}2269 \pm 276 \\
0 \\
192 \pm 19\end{array}$ & $\begin{array}{c}10525 \pm 1462 \\
0 \\
1088 \pm 151\end{array}$ \\
\hline Cyclopoidae & Oithona spp. & $1814 \pm 252$ & 0 & $10184 \pm 1320$ & $578 \pm 59$ & 0 \\
\hline Poecilostomatoida & Corycaeus sp. & $181 \pm 25$ & $1088 \pm 165$ & $55 \pm 72$ & $192 \pm 19$ & $362 \pm 50$ \\
\hline Harpacticoida & Microsetella sp. & 0 & $181 \pm 27$ & $185 \pm 23$ & 0 & 0 \\
\hline Copepod larvae & $\begin{array}{l}\text { Copepodid } \\
\text { Copepoda nauplii }\end{array}$ & $\begin{array}{c}2359 \pm 328 \\
10707 \pm 1490\end{array}$ & $\begin{array}{c}544 \pm 82 \\
29215 \pm 4442\end{array}$ & $\begin{array}{c}2407 \pm 312 \\
25182 \pm 3264\end{array}$ & $\begin{array}{c}770 \pm 79 \\
31004 \pm 3183\end{array}$ & $\begin{array}{c}1633 \pm 277 \\
34663 \pm 4824\end{array}$ \\
\hline Ostracoda & Conchoecia spp. & $363 \pm 50$ & $362 \pm 55$ & $185 \pm 23$ & $192 \pm 19$ & $362 \pm 50$ \\
\hline Decapoda(Hyoplax frater) & $\begin{array}{l}\text { Crab zoea } \\
\text { Crab megalopa } \\
\text { Crab egg }\end{array}$ & $\begin{array}{c}2540 \pm 353 \\
0 \\
0\end{array}$ & $\begin{array}{c}362 \pm 55 \\
0 \\
907 \pm 137\end{array}$ & $\begin{array}{c}185 \pm 23 \\
370 \pm 47 \\
0\end{array}$ & $\begin{array}{c}192 \pm 19 \\
0 \\
192 \pm 19\end{array}$ & $\begin{array}{c}362 \pm 50 \\
0 \\
0\end{array}$ \\
\hline Cirripedia & $\begin{array}{l}\text { Barnacle nauplii } \\
\text { Barnacle Cyprid larvae }\end{array}$ & $\begin{array}{c}1814 \pm 252 \\
0\end{array}$ & $\begin{array}{c}3629 \pm 551 \\
0\end{array}$ & $\begin{array}{c}2036 \pm 264 \\
0\end{array}$ & $\begin{array}{l}384 \pm 39 \\
192 \pm 19\end{array}$ & $\begin{array}{c}9255 \pm 1288 \\
0\end{array}$ \\
\hline Amphipoda & Hyperia & 0 & 0 & 0 & $192 \pm 19$ & 0 \\
\hline Urochordata & Fish embryo & 0 & 0 & $555 \pm 71$ & $384 \pm 39$ & 0 \\
\hline Cnidaria & Actinula larvae & 0 & 0 & $185 \pm 23$ & 0 & 0 \\
\hline Echinodermata & Echinopluteus larvae & 0 & 0 & 0 & 0 & $181 \pm 25$ \\
\hline Mollusca & $\begin{array}{l}\text { Cephalopoda larvae } \\
\text { Gasteropod larvae }\end{array}$ & $\begin{array}{l}181 \pm 25 \\
544 \pm 75\end{array}$ & $\begin{array}{c}0 \\
2177 \pm 331\end{array}$ & $\begin{array}{c}0 \\
1851 \pm 240\end{array}$ & $\begin{array}{c}0 \\
1540 \pm 158\end{array}$ & $\begin{array}{c}181 \pm 25 \\
1269 \pm 176\end{array}$ \\
\hline Protozoa & Tintinnopsis sp. & 0 & $362 \pm 55$ & $185 \pm 23$ & $192 \pm 19$ & $726 \pm 101$ \\
\hline \multicolumn{2}{|c|}{ Unidentified invertebrate eggs } & $3810 \pm 530$ & $181 \pm 27$ & $2036 \pm 264$ & $2269 \pm 276$ & $3991 \pm 555$ \\
\hline \multicolumn{2}{|l|}{ Total abundance (ind. $/ \mathrm{m}^{3}$ ) } & $29573 \pm 4111$ & $42635 \pm 6478$ & $50043 \pm 6543$ & $41118 \pm 4300$ & $65324 \pm 8835$ \\
\hline \multicolumn{2}{|c|}{ Seasonal abundance (ind. $/ \mathrm{m}^{3}$ ) } & & & $45739 \pm 6053$ & & \\
\hline \multicolumn{2}{|c|}{ Dry biomass $\left(\mathrm{mg} / \mathrm{m}^{3}\right)$} & 97.8 & 146.5 & 184.4 & 140.7 & 255.6 \\
\hline \multicolumn{2}{|c|}{ Seasonal mean dry biomass $\left(\mathrm{mg} / \mathrm{m}^{3}\right)$} & & & $165.0 \pm 29.0$ & & \\
\hline
\end{tabular}

Oithona spp= O. oculata, O. nana, O. frigida, O. brevicornis, O. fallax

respectively. Results also indicated that the mouth of the estuary procured the highest zooplankton biomass.

\section{Zooplankton and water quality relationships}

The correlation between water parameters and zooplankton is presented in Table 7. Results showed that there was a significant correlation $(P<0.05)$ between zooplankton abundance and salinity $(r=0.68)$, biomass and salinity ( $r=0.67)$, abundance and dissolved oxygen $(r=-0.59)$ and biomass and dissolved oxygen $(r=-0.54)$, abundance and chlorophyll a $(r=0.71)$, biomass and chlorophyll $a(r=0.68)$. Principle component analysis (PCA) showed that chlorophyll a and salinity had the highest positive correlation while dissolved oxygen had a negative correlation that could describe changes of zooplankton density and biomass in different seasons (Table 8).

\section{DISCUSSION}

Plankton is important for sustainable fisheries management based on biological, ecological, and economical aspects. Evaluation of zooplankton biomass in the estuarine systems for better management of fish and shrimp stocks is essential. There are seasonal variations in biomass and abundance of zooplankton in the estuaries that vary significantly according to the changing water quality, tides and other important factors such as phytoplankton and zooplankton community structures. The biomass and abundance of zooplankton in the present study were the highest in autumn at mouth of HR estuary (station 5). The zooplankton biomass values obtained in HR estuary were among the highest in the literature within Persian Gulf waters. This was due to high thermal tolerance, environmental and reproductive conditions of zooplankton living (Xuelu et al., 2011). In contrary, the reduction of dry biomass and abundance of zooplankton in winter 
Table 5 - Mean $( \pm S E)$ abundance and dry biomass of zooplankton at different stations of Helleh River estuary in winter.

\begin{tabular}{|c|c|c|c|c|c|c|}
\hline \multirow[t]{2}{*}{ Zooplankton } & & \multicolumn{5}{|c|}{ Stations } \\
\hline & & 1 & 2 & 3 & 4 & 5 \\
\hline Calanoidae & $\begin{array}{l}\text { Acartia sp. } \\
\text { Labidocera sp. }\end{array}$ & $\begin{array}{l}0 \\
0\end{array}$ & $\begin{array}{l}0 \\
0\end{array}$ & $\begin{array}{l}0 \\
0\end{array}$ & $\begin{array}{c}113 \pm 14 \\
0\end{array}$ & $\begin{array}{c}0 \\
793 \pm 87\end{array}$ \\
\hline Poecilostomatoida & $\begin{array}{l}\text { Oncaea sp. } \\
\text { Corycaeus sp. }\end{array}$ & $\begin{array}{l}0 \\
0\end{array}$ & $\begin{array}{c}0 \\
108 \pm 16\end{array}$ & $\begin{array}{c}0 \\
210 \pm 34\end{array}$ & $\begin{array}{l}0 \\
0\end{array}$ & $\begin{array}{c}340 \pm 37 \\
0\end{array}$ \\
\hline Copepod larvae & Copepoda nauplii & $555 \pm 72$ & $980 \pm 149$ & $632 \pm 103$ & $113 \pm 14$ & $4646 \pm 511$ \\
\hline Ostracoda & Conchoecia spp. & $222 \pm 28$ & $218 \pm 33$ & 0 & 0 & $906 \pm 99$ \\
\hline Amphipoda & Hyperia & 0 & $108 \pm 16$ & 0 & 0 & 0 \\
\hline Urochordata & Oikopleura sp. & 0 & 0 & 0 & 0 & $266 \pm 24$ \\
\hline Cnidaria & $\begin{array}{l}\text { Siphonophora } \\
\text { Phialidium }\end{array}$ & $\begin{array}{l}0 \\
0\end{array}$ & $\begin{array}{c}108 \pm 16 \\
0\end{array}$ & $\begin{array}{c}104 \pm 17 \\
0\end{array}$ & $\begin{array}{l}0 \\
0\end{array}$ & $\begin{array}{c}0 \\
2946 \pm 324\end{array}$ \\
\hline Ctenophora & Boliopsis sp. & $333 \pm 43$ & 0 & 0 & 0 & 0 \\
\hline Mollusca & $\begin{array}{l}\text { Cephalopoda larvae } \\
\text { Gasteropod larvae }\end{array}$ & $\begin{array}{l}0 \\
0\end{array}$ & $\begin{array}{l}326 \pm 49 \\
108 \pm 16\end{array}$ & $\begin{array}{l}206 \pm 37 \\
207 \pm 73\end{array}$ & $\begin{array}{c}0 \\
113 \pm 14\end{array}$ & $\begin{array}{l}340 \pm 37 \\
266 \pm 24\end{array}$ \\
\hline Nematod & Pratylenchus spp. & $1444 \pm 187$ & $326 \pm 49$ & $210 \pm 34$ & $906 \pm 113$ & $113 \pm 11$ \\
\hline Protozoa & Discorbis sp. & 0 & $326 \pm 49$ & 0 & $113 \pm 14$ & 0 \\
\hline \multicolumn{2}{|c|}{ Unidentified invertebrate eggs } & $333 \pm 43$ & $544 \pm 82$ & $737 \pm 120$ & $113 \pm 14$ & $5780 \pm 636$ \\
\hline \multicolumn{2}{|c|}{ Total abundance (ind. $/ \mathrm{m}^{3}$ ) } & $2887 \pm 373$ & $3152 \pm 475$ & $2306 \pm 418$ & $1471 \pm 183$ & $16396 \pm 1790$ \\
\hline \multicolumn{2}{|c|}{ Seasonal abundance (ind. $/ \mathrm{m}^{3}$ ) } & \multicolumn{5}{|c|}{$5242 \pm 648$} \\
\hline \multicolumn{2}{|c|}{ Dry biomass (mg/m3) } & 11.0 & 11.6 & 8.3 & 5.5 & 68.2 \\
\hline \multicolumn{2}{|c|}{ Seasonal mean dry biomass $(\mathrm{mg} / \mathrm{m} 3)$} & & & $20.9 \pm 13.3$ & & \\
\hline
\end{tabular}

can be related to low water temperatures, poor living conditions and reduction of photosynthetic primary production and chlorophyll a (Omori \& Ikeda, 1984; Day et al., 1989). In addition to the relative small mesh sized net $(140 \mu \mathrm{m})$ employed, some of the smaller zooplankton components were caught, which, in turn, might have increased the biomass values as reported by Morioka et al. (1990) and Nakashima et al. (1992). The depth of sampling in different sampling stations in HR was almost less than $2.5 \mathrm{~m}$, indicating that the shorter distance of vertical haul might have also given the larger component of phytoplankton in the net collection.

Different groups of zooplankton were identified in this estuary. The copepod, mostly calanoid, was the dominant assemblage in HR estuary. Similar zooplankton groups were common in other estuaries (Tiwari and Nair, 1993; Wooldridge and Callahan, 2000; Primo et al., 2009; Hwang et al., 2010; Xuelu et al., 2011). In fact, distribution of zooplankton populations is mostly governed by various behavioral and physiological adaptations to ever changing hydrographical conditions (Mohan et al., 1999). It depends on the regime of individual estuaries which varies according to climate and the catchments area of its feeder river. Furthermore, Vucetic (1973) maintains that the geographic distribution of zooplankton depends on the different conditions for feeding and reproduction in various biotopes. The mudflats biotope of HR estuary makes water rich in some important nutrients from bottom into the water column and increases the primary production and chlorophyll a (Chua, 1970).

The various features of estuarine ecosystems stem from salinity gradient along estuary. This is mainly due to the strength of diurnal tidal current, which comes from the sea and the volume of freshwater flow from the upstream. In this study, salinity had a positive correlation (Table 7) and it was an effective factor (Table 8) on abundance and biomass of zooplankton, especially at mouth of estuary. Salinity affects the overall composition of the zooplankton community and also, the individual species at different stages of their life cycle (Day et al., 1989). In addition, salinity is the most important factor influencing the community structure of zooplankton populations in tropical and subtropical estuaries (Lee and Olsen, 1985; Mitral et al., 1990; Lopes, 1994, Nasser et al., 1998; Hwang et al., 2010) as well as zooplankton density (Fernandex de Puelles et al., 2003; Hwang et al., 2010). Moreover, Mishara and Panigrahy (1999) noted salinity as the most important factor in the distribution of zooplankton (specifically copepods) in the estuaries. They reported that freshwater flowing into estuaries decreased the zooplankton densities.

In some cases, other physico-chemical parameters such as Secchi disk and chlorophyll a have some 
Braz. J. Aquat. Sci. Technol., 2014, 18(2):19-29.

Table 6 - Mean ( \pm SE) abundance and dry biomass of zooplankton at different stations of Helleh River estuary in spring.

\begin{tabular}{|c|c|c|c|c|c|c|}
\hline \multirow[t]{2}{*}{ Zooplankton } & & \multicolumn{5}{|c|}{ Stations } \\
\hline & & 1 & 2 & 3 & 4 & 5 \\
\hline Polychaete & $\begin{array}{l}\text { Tomopteris } \\
\text { Trochophore } \\
\text { Veliger }\end{array}$ & $\begin{array}{l}0 \\
0 \\
0\end{array}$ & $\begin{array}{c}362 \pm 63 \\
0 \\
1269 \pm 222\end{array}$ & $\begin{array}{c}0 \\
533 \pm 85 \\
711 \pm 113\end{array}$ & $\begin{array}{c}370 \pm 47 \\
370 \pm 47 \\
0\end{array}$ & $\begin{array}{c}740 \pm 110 \\
370 \pm 55 \\
370 \pm 55\end{array}$ \\
\hline Calanoidae & $\begin{array}{l}\text { Acartia sp. } \\
\text { Paracalanus sp. }\end{array}$ & $\begin{array}{c}544 \pm 75 \\
0\end{array}$ & $\begin{array}{l}0 \\
0\end{array}$ & $\begin{array}{r}177 \pm 28 \\
711 \pm 113\end{array}$ & $\begin{array}{c}925 \pm 120 \\
0\end{array}$ & $\begin{array}{c}925 \pm 137 \\
370 \pm 55\end{array}$ \\
\hline Cyclopoidae & Oithona spp. & $362 \pm 50$ & $362 \pm 63$ & $177 \pm 28$ & $555 \pm 72$ & $370 \pm 55$ \\
\hline Poecilostomatoida & Oncaea sp. & $181 \pm 25$ & 0 & $355 \pm 56$ & $370 \pm 47$ & $555 \pm 82$ \\
\hline Harpacticoida & $\begin{array}{l}\text { Euterpina sp. } \\
\text { Microsetella sp. }\end{array}$ & $\begin{array}{c}181 \pm 25 \\
0\end{array}$ & $\begin{array}{l}0 \\
0\end{array}$ & $\begin{array}{c}0 \\
355 \pm 56\end{array}$ & $\begin{array}{c}0 \\
370 \pm 47\end{array}$ & $\begin{array}{l}370 \pm 55 \\
370 \pm 55\end{array}$ \\
\hline Copepod larvae & $\begin{array}{l}\text { Copepodid } \\
\text { Copepoda nauplii }\end{array}$ & $\begin{array}{c}362 \pm 50 \\
1814 \pm 252\end{array}$ & $\begin{array}{c}0 \\
1452 \pm 254\end{array}$ & $\begin{array}{c}355 \pm 56 \\
1244 \pm 198\end{array}$ & $\begin{array}{c}0 \\
4259 \pm 552\end{array}$ & $\begin{array}{c}740 \pm 110 \\
6110 \pm 910\end{array}$ \\
\hline Ostracoda & Conchoecia spp. & 0 & $1088 \pm 190$ & $355 \pm 56$ & $370 \pm 47$ & $555 \pm 82$ \\
\hline Cumacea & Diastylis sp. & 0 & 0 & $177 \pm 28$ & 0 & 0 \\
\hline $\begin{array}{l}\text { Decapoda } \\
\text { (Hyoplax frater) }\end{array}$ & Crab zoea & $181 \pm 25$ & 0 & $177 \pm 28$ & 0 & $370 \pm 55$ \\
\hline $\begin{array}{l}\text { Cirripedia } \\
\text { (Balanus improvisus) }\end{array}$ & $\begin{array}{l}\text { Barnacle nauplii } \\
\text { Barnacle Cyprid larvae }\end{array}$ & $\begin{array}{c}362 \pm 50 \\
0\end{array}$ & $\begin{array}{l}0 \\
0\end{array}$ & $\begin{array}{l}0 \\
0\end{array}$ & $\begin{array}{c}0 \\
185 \pm 23\end{array}$ & $\begin{array}{c}1110 \pm 165 \\
0\end{array}$ \\
\hline Amphipoda & Hyperia & 0 & 0 & 0 & 0 & $185 \pm 27$ \\
\hline Aschelminthes & Brachionus plicatilis & $362 \pm 50$ & 0 & $355 \pm 56$ & 0 & $740 \pm 110$ \\
\hline Urochordata & $\begin{array}{l}\text { Fish embryo } \\
\text { Oikopleura sp. }\end{array}$ & $\begin{array}{c}726 \pm 101 \\
0\end{array}$ & $\begin{array}{l}0 \\
0\end{array}$ & $\begin{array}{c}0 \\
177 \pm 28\end{array}$ & $\begin{array}{c}0 \\
555 \pm 72\end{array}$ & $\begin{array}{c}555 \pm 82 \\
2407 \pm 358\end{array}$ \\
\hline Cnidaria & Siphonophora & 0 & 0 & $355 \pm 56$ & 0 & $555 \pm 82$ \\
\hline Mollusca & $\begin{array}{l}\text { Cephalopoda larvae } \\
\text { Gasteropod larvae }\end{array}$ & $\begin{array}{c}362 \pm 50 \\
0\end{array}$ & $\begin{array}{c}362 \pm 63 \\
1269 \pm 222\end{array}$ & $\begin{array}{l}1244 \pm 198 \\
1955 \pm 311\end{array}$ & $\begin{array}{c}555 \pm 72 \\
925 \pm 120\end{array}$ & $\begin{array}{c}370 \pm 55 \\
1259 \pm 193\end{array}$ \\
\hline Nematod & Pratylenchus spp. & $544 \pm 75$ & $726 \pm 127$ & $533 \pm 85$ & $555 \pm 72$ & $925 \pm 137$ \\
\hline Protozoa & Tintinnopsis sp. & $181 \pm 25$ & 0 & 0 & $555 \pm 72$ & $370 \pm 55$ \\
\hline Unidentified invertebra & te eggs & $1814 \pm 252$ & $907 \pm 158$ & $1600 \pm 254$ & $1150 \pm 111$ & $4259 \pm 634$ \\
\hline Total abundance (ind./ & $\left.m^{3}\right)$ & $7976 \pm 1105$ & $7797 \pm 1362$ & $11546 \pm 1607$ & $12069 \pm 1521$ & $24950 \pm 3741$ \\
\hline Seasonal abundance & (ind. $/ \mathrm{m}^{3}$ ) & & & $12905 \pm 1867$ & & \\
\hline Dry biomass $\left(\mathrm{mg} / \mathrm{m}^{3}\right)$ & & 27.4 & 28.5 & 43.6 & 47.6 & 102.5 \\
\hline Seasonal mean dry bi & omass $\left(\mathrm{mg} / \mathrm{m}^{3}\right)$ & & & $49.9 \pm 15.4$ & & \\
\hline
\end{tabular}

Oithona spp= O. oculata, O. nana, O. frigida, O. brevicornis, O. fallax

Table 7 - Pearson correlation coefficients between some of the properties of water with abundance and biomass of zooplankton biomass in Helleh River estuary.

\begin{tabular}{lcc}
\hline \hline Parameter & Abundance & Biomass \\
\hline Temperature & $0.113(0.634)$ & $0.075(0.754)$ \\
Salinity & $0.677^{* *}(0.001)$ & $0.671^{* *}(0.001)$ \\
Dissolved oxygen & $-0.589^{* *}(0.006)$ & $-0.537^{* *}(0.015)$ \\
$\mathrm{pH}$ & $0.121(0.612)$ & $0.184(0.438)$ \\
Secchi depth & $-0.240(0.921)$ & $0.004(0.988)$ \\
Chlorophyll a & $0.708^{* *}(0.001)$ & $0.682^{* *}(0.001)$ \\
$\mathrm{PO}_{4}$ & $0.411(0.072)$ & $0.443(0.051)$ \\
$\mathrm{NO}_{3}$ & $-0.041(0.864)$ & $-0.070(0.771)$ \\
\hline
\end{tabular}

**: Significant correlation in 0.01 level. Data in parenthesis are F-values. 
Table 8 - Seasonal PCA analysis of zooplankton abundance, biomass and water quality parameters at Helleh River estuary.

\begin{tabular}{lccc}
\hline \hline & \multicolumn{3}{c}{ Components } \\
Parameters & 1 & 2 & 3 \\
\hline Temperature & 0.785 & 0.228 & -0.424 \\
Salinity & 0.822 & 0.000 & 0.045 \\
Dissolved oxygen & -0.881 & 0.344 & 0.223 \\
$\mathrm{pH}$ & 0.168 & 0.347 & 0.719 \\
Secchi depth & -0.394 & 0.653 & 0.179 \\
Abundance & 0.841 & 0.476 & -0.164 \\
Biomass & 0.822 & 0.517 & -0.095 \\
Chlorophyll a & 0.655 & 0.425 & -0.195 \\
$\mathrm{PO}_{4}$ & 0.573 & -0.067 & 0.581 \\
$\mathrm{NO}_{3}$ & 0.298 & -0.527 & 0.272 \\
$\mathrm{Percent}$ & 41.76 & 21.54 & 10.91 \\
\hline \hline
\end{tabular}

effects on zooplankton biomass. According to Nair et al (1981), zooplankton biomass was declined with the increase of turbidity of water in an Indian estuary. On the other hand, density of copepod Acartidae had a positive correlation with chlorophyll a in La Habana (Cuba) (Lee and Olsen, 1985; Zaballa and Gaudy, 1996). In the current study, chlorophyll a had a positive correlation and also, it was effective factor (based on PCA analysis) on zooplankton density and biomass at sampling locations (stations), especially at the mouth of estuary. However, this significance correlation indicated that zooplankton biomass was regulated mostly by food supply and quality of food (Verity, 1987). The availability of food items is one of the major factors determining the zooplankton distribution (Cox and Wiebe, 1979; Mitra et al., 1990; Park and Marshall; 2000).

In this study, temperature had a poor correlation with the density and biomass of zooplankton. Although several authors (Madhupratap, 1987; Mishra and Panigrahy, 1999) showed that temperature had an insignificant effect on tropical zooplankton populations, some available literature (Osore, 1992; Lopes, 1994; Nasser et al., 1998) noted temperature as an important factor affecting the abundance and distribution of zooplankton populations. According to Day et al (1989), the main factors of temperature, food supply and predation controlled zooplankton distribution in estuarine ecosystems.

The seasonal study in HR estuary showed that dissolved oxygen had a negative correlation with density and biomass. In addition, dissolved oxygen is the other critical variable that should be considered in evaluating the water quality in estuaries. The low dissolved oxygen concentration of a water body directly affects the survival of aquatic organisms, thereby altering estuarine healthy ecological balance (Zheng et al., 2004). Frequent occurrences of hypoxia due to the sudden decrease of dissolved oxygen caused the significant reduction of fishery harvests, toxic algal blooms and the loss of biotic diversity (Pearl, 1988; Howarth et al., 2000). The variances of dissolved oxygen in estuaries were controlled by physical and biochemical processes (Ambrose et al., 1993; Chen 2003). According to Upadhyay (1988), the high concentration of dissolved oxygen was also correlated with high $\mathrm{pH}$. In all seasons, $\mathrm{pH}$ was in alkaline range and based on PCA analysis, it was a very effective factor on stations with the highest density and biomass. Alkaline $\mathrm{pH}$ usually provides the best conditions for the growth of zooplankton (Arnott and Vanni, 1993; Bhuiyan and Nessa, 1998).

To conclude, this research showed that the highest density and biomass of zooplankton was at mouth area of estuary in all seasons which had a positive significant correlation with salinity and chlorophyll a in HR estuary, Persian Gulf.

\section{ACKNOWLEDGMENTS}

Authors are thankful to Isfahan University of Technology (IUT) and also, Iran Shrimp Research Center (ISRC) for giving financial support and Persian Gulf University for providing technical assistance.

\section{REFERENCES}

Ambrose, Jr. R. B., Wool, T. A. \& Martin, J. L. 1993. The water quality analysis simulation program, WASP5, Part A: F Model documentation. U.S. Environmental Protection Agency, Athens, Georgia.

Arnott, S. E. \& Vanni, M. J. 1993. Zooplankton assemblages in Fishless bog lakes: Influence of biotic and abiotic factors. Ecology 74: 2361-2380.

Baird, D., Hanekom, N.M. \& Grindley, J.R. 1986. Estuaries of the Cape. Part II. Synopses of available information on individual systems. Report No. 23. Swarkopes (CSE3). CSIR Research Report, $422 \mathrm{pp}$.

Bhuiyan, A. S. \& Nessa, Q. 1998, A quantitative study of zooplankton in relation to the physico-chemical conditions of a freshwater fish pond of Rajshahi. University Journal of Zoology, Rajshahi University, 17: 29-37.

Carlberg, S. R. 1980. Oil pollution of the marine environment- With an emphasis on estuarine studies. In: Olausson, E. \& Cato, I. (eds.) Chemistry and Biogeochemistry of estuaries. . John Willey \& Sons, 367-402.

Chau, H. 1999. Overview of water environment properties in Hong Kong. Water Sci. Technol., 40: 91-96. 
Chen, C. 2003. Marine ecosystem dynamics and modeling. New Frontier of Science. Higher Education Press of China.

Chi-Fang, W., Hsu, M. H. \& Kuo, A. Y. 2004. Residence time of the Danshuei River estuary, Taiwan. Estuar. Coast Shelf Sci. 60: 381-393.

Chihara, M. \& Murano, M. 1997. An Illustrated Guide to Marine Plankton in Japan. Tokai University Press. Japan.

Chua, T. E. 1970. A preliminary study on the plankton of the Ponggol Estuary. Hydrobiologia 35: 254-272.

Costanza, R. Farber, S. C. \& Maxwell, J. 1989. Valuation and management of wetland ecosystems. Ecol. Econ. 1: 335-361.

Cox, J. \& Wiebe, P. H. 1979. Origins of oceanic plankton in the middle Atlantic Bright. Estuar Coast Shelf S, 9, 509-527.

Day, J. W., Hall, C. A. S., Kemp, W. M. \& YanezArancibia, A. 1989. Estuarine Ecology. A. WileyInterscience Publication, John Wiley and Sons Ltd, New York, 558 pp.

Deegan, L. \& Day, J. W. 1985. Estuarine fish habitat requirements. In: Research for managing Nationss estuaries. Edited by B. Copeland, K. Hart, N. Davis and S. Friday. UNC Sea Grant College Publication. North Caroline University. USA, 315-336.

Grice, G. D. \& Gibson, V. R. 1978. General biological oceanographic data from the Persian Gulf and Gulf of Oman. Woods Hole Oceanographic Institution, Woods Hole, Massachusetts, $39 \mathrm{p}$.

Grindley, J. R. 1981. Estuarine Plankton. In Estuarine Ecology with particular reference to South Africa. Edited by Day J. H., and Balkema A. A., Rotterdam, 117-146.

Harris, R., Wiebe, P. H., Lenz, J., Skjoldal, H. R. \& Huntley, M. 2000. Introduction in ICES zooplankton methodology manual. Academic Press.

Howarth, R., Swaney, D., Bulter T. \& Marino, R. 2000. Climatic control on eutrophication of the Hudson River estuary. Ecosystems, 3, 210-215.

Hwang, J. S., Kumar, R., Hsieh, C. W., Kuo, A.Y., Souissi, S., Hsu, M. H., Wu, J. T., Liu, W. C., Wang, C. F. \& Chen, Q. C. 2010. Pattern of zooplankton distribution along the marine, estuarine, and riverine portions of the Danshuei ecosystem in northern Taiwan. Zool. Stud, 49, 335-352.

Jayansinghe, R. P. P. K. 2004. Zooplankton populations along a salinity gradient in a tropical estuary giving emphasis to copepods. Master science thesis, University Putra Malaysia, 139 pp.

Jennerjahn, T. C., Ittekkot, V., Klopper, S., Adi, S., Nogroho, S. P., Sudiana, N., Yusmal, A. \& GayeHaake, B. 2004. Biogeochemistry of a tropical river affected by human activities in its catchment: Brantas river estuary and coastal waters of Madura
Strait, Java, Indonesia. Estuar Coast Shelf Sci. 60: 503-514.

Joseph, B. \& Yamakanamardi, S. M. 2011. Monthly changes in the abundance and biomass of zooplankton and water quality parameters in Kukkarahalli Lake of Mysore, India. J. Environ. Biol. 32: 551-557.

Khodadadi, M. 1993. Identification and abundance of plankton in Persian Gulf (from Bahre Kansar to Nayband Gulf), Fisheries Research Center of Persian Gulf, Iranian Fisheries Research Institute. $45 \mathrm{pp}$.

Knox, G. A. 1986. Estuarine ecosystems: a systems approach. Volume 1. CRC Press, Inc. Boca Raton, Florida.

Kress, N., Coto, S. L., Brenes, C. L., Brenner, S. \& Arroyo, G. 2002. Horizontal transport and seasonal distribution of nutrients, dissolved oxygen and chlorophyll a in the Gulf of Nicoya, Costa Rica: a tropical estuary. Cont. Shelf Res. 22: 51-66.

Lee, V. \& Olsen, S. 1985. Eutriphication and management initiatives for the control of nutrient inputs to Rhode Island lagoon. Estuaries 8: 191-202.

Lopes, R. M. 1994. Zooplankton distribution in the Guarau River estuary (South-Eastern Brazil). Estuar Coast Shelf Sci. 39: 287-302.

Madhupratap, M. 1987. Status and Strategy of zooplankton of tropical Indian estuaries: A review. Bull. Plankton Soc. Jpn. 34: 65-81.

Maguire, G. B., Gibbs, P. J. \& Collett, L. C. 1985. The macrobenthic faune of brackish water prawn farming ponds at Port Stephens New South Wales. Aust. J. Zool. 21: 445-458.

Mann, K. H. 2000. Ecology of coastal waters: with implications and management. 2nd Edition, Blackwell Science Publishers, USA.

Michel, H. B. \& Herring, D. C. 1984. Diversity and abundance of Copepoda in the northwestern Persian Gulf. Crustaceana, Supplement 7, Studies on Copepoda ii: 326-335.

Miller Jr, G. T. \& Spoolman, S. E. 2012. Living in the Environment. Published by Yolanda Cossia, 17th Edition, $804 \mathrm{pp}$.

Mishra, S. \& Panigrahy, R. C. 1999. Zooplankton ecology of the Bahuda estuary (Orissa), East coast of India. Indian J. Mar. Sci. 28: 297-301.

Mitra, A., Patra, K. C. \& Panigrahy, R. C. 1990. Ecology of Planktonic copepods in the Mandarmani creek of West Bengal, India. Indian J. Mar. Sci. 19: 278-281.

Mohan, P. C., Roman, A. V. \& Sreenivas, N. 1999. Distribution of zooplankton in relation to water currents in Kakinada Bays East Coast of India. Indian J Mar Sci, 28, 192-197. 
Monchenko, V. I. 1974. Cyclopidae. Fauna Ukrainii 27: 1-452.

Moore, E. A. \& Sander, F. 1979. A comparative study of zooplankton from oceanic, shelf, harbor waters of Jamaica. Biotropica 11: 196-206.

Morioka, Y., Nakashima, J. \& Katsunori, K. 1990. Zooplankton biomass share of the collection with plankton net in the waters to the west of Kyushu, March 1987. Bull. Seikai Natl. Fish. Res. Inst. 68: 143-151.

Morton, B. \& Blackmore, G. 2001. South China Sea. Mar. Pollut. Bull. 42: 1236-1263.

Nair, V. R, Gajbhiye, S. N., Ram, M. J. \& Desai. B. N. 1981. Biomass and composition of zooplankton in Auranga, Ambika, Purna \& Mindola estuaries of South Gujarat. Indian J. Mar. Sci. 27: 346-360.

Nakashima, J., Morioka, Y. \& Katsunori, K. 1992. Further investigation of zooplankton share in the collections with plankton net in the waters to the west of Kyushu. Bull. Seikai Natl. Fish. Res. Inst. 70: 47-51.

Nasser, A. K. V., Siraimeetan, P. \& Aboobakr P. M. 1998. Zooplankton abundance and distribution at Minicoy lagoon, Lakshadweep. Indian J. Mar. Sci. 27: 346-360.

Nishida, S. 1985. Taxonomy and distribution of the family Oithonidae (Copepoda, Cyclopoida) in the Pacific and Indian oceans. Bull. Ocean Res. Inst., Univ. Tokyo 20, 167 pp.

Omori, M. \& Ikeda, T. 1984. Methods in zooplankton ecology. John Wiley \& Sons, New York, 332 pp.

Osore, M. K. W. 1992. A note on the zooplankton distribution and diversity in a tropical mangrove creek system, Gazi, Kenya. Hydrobiologia 247: 119-120.

Park, G. S. \& Marshall, H. G. 2000. Estuarine relationships between zooplankton community structure and trophic gradients. J. Plankton Res., 22: 121-135.

Parsons, T. R., Maita, Y. \& Lalli, C. M. 1984. A manual of chemical and biological methods for seawater analysis. Pergamon Press, Oxford.

Pearl, H.W. 1988. Nuisance phytoplankton blooms in coastal estuarine and inland waters. Limnol. Oceanogr. 33: 823-847.

Postel, L., Fock, H. \& Hagen, W. 2000. Biomass and abundance. In ICES Zooplankton Methodology Manual. In: R. Harris, P. H. Wiebe, J. Lenz, H. R. Skjoldal \& M. Huntley (eds.), Academic Press, 83-192 pp.

Primo, A. L., Azeiteiro, U. M., Marques, S. C., Martinho, F. \& Pardal, M. A. 2009. Changes in zooplankton diversity and distribution pattern under varying precipitation regimes in a southern temperate estuary. Estuar. Coast Shelf Sci., 82: 341-347.
Rabbanih, M., Izadpanahi, G., Owfi, F. \& Mohsenizadeh, F. 2011. Plankton community assemblage in surface layers of Northern part of the Persian Gulf (Iran -Bushehr area), using by PCA. In: Proceeding of International Symposium on "Marine Ecosystems, Natural Products and their Bioactive Metabolites.

Rezaei Marnani, H. 2002. Ecological studies on zooplankton from the Straits of Malacca with special reference to copepods. Ph. D thesis, University Putra Malaysia, $265 \mathrm{pp}$.

ROPME - Regional Organization for the Protection of the Marine Environment 2003. State of the marine environment report 2003, Kuwait, pp. 18-27.

Ross, S. \& Epperly, S. 1985. Utilization of shallow nursery areas by fishes in Pamlico Sound and adjacent tributaries, North Carolina. In: YancyAramcibia (Ed.), Fish Community Ecology in Estuaries and Coastal Lagoons. Towards an Ecosystem Integration, UNAM Press, Mexico City, 207-232 pp.

Savari, A. 1982. Preliminary survey of plankton in Bushehr, Kangan, Iranian Shrimp Research Organizatio, Iran.

Sirinivasan, A. \& Santhanam, R. 1991. Tidal and seasonal variations in zooplankton of Pullavazhi brackishwater, Southeast coast of India. Indian J. Mar. Sci. 20:182-186.

Suthers, I. M. \& Rissik, D. 2009. Plankton: A guide to their ecology and monitoring for water quality. CSIRO Publishing, Collingwood, Australia, 256 pp.

Teimori, A., Esmaeili, H. R. \& Golam Hosseini, A. 2010. The ichthyofauna of Kor and Helleh River Basins in southwest of Iran with reference to taxonomic and zoogeographic features of native fishes. Iran J An. Biosystematics 6: 1-8.

Tiwari, L. R. \& Nair, V. R. 1993. Zooplankton distribution in Dharamtar creek adjoining Bombay harbor. Indian J. Mar. Sci. 22: 19-23.

Todd, C.D., and Laverack, M.S. 1991. Coastal marine zooplankton: a practical manual for students, Cambridge University Press, $106 \mathrm{p}$.

Upadhyay, A. 1988. Physcio-chemical characteristics of the Mahanada Ecosystem, East Coast of India. Indian J. Mar. Sci. 17: 63-69.

Verity, P. G. 1987. Abundance, community composition, size distribution, and production rates of tintinnids in Narragansett Bay, Rhode Island. Estuar Coast Shelf Sci. 24: 671-690.

Vucetic, B. A. 1973. Zooplankton and circulation patterns of the water masses in the Adriatic. Neth. J. Sea Res. 7: 112-121.

Wooldridge, T. H. \& Callahan, R. 2000. The effect of single freshwater release into the Kromme Estuary. 
3: Estuarine zooplankton response. Water S. A., 26: 311-318.

Xuelu, G., Jinming, S. \& Xuegang, L. 2011. Zooplankton spatial and diurnal variations in the the changjiang River estuary before operation of the Three Gorges Dam. Chin. J. Oceanol. Limnol. 29: 591-602.

Zabella, J. D. \& Gaudy, R. 1996. Seasonal variations in the zooplankton and in the population structure of Acartia tonsa in a very eutrophic area: La Habana Bay (Cuba). J. Plankton Res. 18: 1123-1135.
Zar, J. H. 1984. Bioststistical analysis, 2nd edition. Prentice Hall Inc., Englewood Cliffs, New York, USA, $718 \mathrm{pp}$.

Zheng, L., Chen, C. \& Zhang, F.Y. 2004. Development of water quality model in Satilla Estuary, Georgia. Ecol. Model. 178: 457-482.

Submetido: Setembro/2013 Revisado: Junho/2014 Aceito: Julho/2014 